Catherine Heinemeyer*

ORCID: 0000-0001-6300-5544

York, England

\title{
Figures on a Windswept Shore: The Interplay of Aloneness and Communitas in Oral Storytelling
}

\author{
Postaci na wichrowym brzegu. \\ Wspólzależność samotności i wspólnotowości \\ w ustnym opowiadaniu historii
}

\begin{abstract}
Storytelling is an artistic practice which is often understood as generating a sense of togetherness, or, to use Victor Turner's (1969) more specific term, 'communitas'. Yet in my experience as a storyteller with young people in many contexts, including mental health settings, aloneness is an equally important feature of storytelling gatherings. Many stories feature lonely characters, and telling such stories calls on the teller's own experiences of being alone. Many listeners appreciate being left alone for the duration of the story, and respond to it privately. Observing this has often brought to my mind the image of the story as a rocky shore, on which the listeners are wandering separately while aware of each other's presence. In this essay I interweave the story of 'The Stolen Child', a fairy tale featuring an isolated young woman, with observations from two youth mental health settings in which I led storytelling workshops. In so doing, I seek to illustrate the interdependence of aloneness and togetherness in oral story-sharing, as encapsulated in Jean-Luc Nan-

* Catherine Heinemeyer Ph.D., Department of Drama and Theatre, York St John University. email: c.heinemeyer@yorksj.ac.uk.
\end{abstract}


cy's observation (1991, p. 35) that 'singular beings lean together'. There is thus no simple opposition between aloneness and communitas; I offer tentative experiential evidence that moments of surprising connection can be enabled by giving listeners permission to first be separate.

Keywords: storytelling; aloneness; communitas; enstasy; young people; storytelling in mental health.

Abstrakt: Opowiadanie historii jest artystyczną praktyką, rozumianą często jako tworzenie poczucia bycia razem, lub, używając bardziej dokładnego terminu autorstwa Victora Turnera (1969), 'communitas' - wspólnoty. Jednak moje doświadczenie jako gawędziarza (storyteller) w pracy z młodymi ludźmi w wielu kontekstach, w tym klinik zdrowia psychicznego, ukazuje samotność jako równie istotną cechę spotkań mających na celu opowiadanie historii. Wiele opowieści przedstawia osamotnione postacie i opowiadanie o nich przywołuje własne doświadczenie osamotnienia snującego narrację. Wielu słuchaczy ceni możliwość pozostawienia ich samych na czas trwania historii i zareagowania na nią prywatnie. Obserwowanie tego nasuwało mi często alegorię opowieści jako skalistego brzegu, na którym każdy ze słuchaczy wędruje osobno, pozostając świadomym obecności innych. W niniejszym eseju ,przeplatam” historię pt. „Skradzione Dziecko”, baśń o wyizolowanej młodej kobiecie, ze spostrzeżeniami z dwóch klinik zdrowia psychicznego dla młodzieży, w których prowadziłam warsztaty z opowiadania historii (storytelling). W ten sposób staram się zilustrować współzależność samotności i wspólnotowości w ustnym przekazywaniu historii, na którą zwrócił uwagę Jean-Luc Nancy (1991, s. 35), pisząc, iż „pojedyncze byty wspierają się razem”. Tak więc nie sposób mówić o prostym przeciwstawieniu sobie samotności i wspólnotowości; oferuję nieśmiało eksperymentalny dowód, iż momenty zaskakującego połączenia umożliwia uprzednie pozwolenie, by być oddzielonym.

Słowa kluczowe: opowiadanie historii; samotność; wspólnota; wewnętrzność; młodzi ludzie; opowiadanie historii a zdrowie psychiczne.

\section{Introduction}

For two years I held a storytelling residency at Maple House ${ }^{1}$, a mental health inpatients' unit for adolescents. Every week I held a storytelling work-

${ }^{1}$ Pseudonym for the setting. 
shop with a group of those who wished to take part, among the young people currently resident. In agreement with the setting's staff, the aim was not therapeutic per se, but to provide opportunities for open-ended creative engagement, absorption, expression and connection. Thus, workshops involved a mixture of elements: stories told by me; stories composed by individual young people or collectively by the group; games and crafts responding to their themes, or simply chosen by the young people; and visual art, drama or song-writing, to extend or develop stories.

Any storyteller (or theatre-maker) is always conscious of the interplay between the story or text they are presenting, and the context in which they are presenting it. As Gaylord explains,

the theatrical occasion involves double consciousness for all concerned. The performance takes place on at least two levels of 'reality' simultaneously and within at least two frames. The outer frame always embraces both audience and performers. The inner frame demarcates the playing space. (Gaylord, 1983, p. 136)

Therefore, in this article I weave together a rough transcript of 'The Stolen Child', a story I told during one memorable workshop at Maple House, with my observations of how this and other stories were received in that setting. In so doing, I aim to illustrate my slowly acquired understanding of the interdependence between the ability of storytelling to engender solitude, and its tendency to reach towards a kind of togetherness or connection. To amplify this discussion I will also draw on another project, The Tale Exchange (2017), which experimented more explicitly with this interplay, and specifically with the possibility of a meeting of minds 'around corners' (Heinemeyer, 2018).

\section{Listening together}

\section{The Stolen Child (1)}

It was a wild day of high winds in a little town clustered against a jagged shoreline. A young woman entered on foot from the road inland. She wore a shapeless dark-coloured dress but if you looked carefully you could see the swell of her belly. She knocked first at one door, then the next, but each of them closed in her face, until when she reached the far end of the town she gave up and stood 
for a minute looking around her, clutching her back. The time had come for her to give birth to her child and the pains were coming closer together.

She picked her way down onto the rocky shore, avoiding the slippery seaweed, feeling the slap of spray off the sea on her neck and face, and clambered over rocks until she found a platform sheltered by a boulder. She crouched down on her hunkers and it was not much longer until her child was born. A little boy, his cries almost drowned by the wind. She held him up for just one moment to see he was whole and hers, then quickly tucked him inside her dress, against her chest to keep warm, leaned her back against the rock and fell into an exhausted, dreamless sleep.

Storytelling is a practice riddled with metaphors of 'communitas', a term coined by the anthropologist Victor Turner to describe the way in which rituals or performances may bring a society together, usually temporarily, without hierarchy or social divisions:

... as an unstructured or rudimentarily structured and relatively undifferentiated comitatus, community, or even 'communion' of equal individuals who submit together to the general authority of the ritual elders. (Turner, 1969, p. 95)

While a storyteller is not a 'ritual elder', the aspiration to bring an audience into a shared 'liminal' or threshold state (Turner, 1969) between fiction and reality is highly celebrated among performers of all kinds. The widely held belief that storytelling engenders communitas becomes concretised, for many aficionados of storytelling, by individual experience. Often, when I have been among a storyteller's audience, I have felt a convergence between me and those others gathered, a slowing of each person's breathing rate, and a confluence of focus on the images formed somewhere between the teller's words and our own minds. Storyteller Geoff Mead (2011) describes a physical sensation of vibrating on the same wavelength as others present in the room, while he is telling or listening to others tell stories. Moreover, research confirms the empirical existence of this phenomenon. Fran Stallings (1988) assembles evidence from psychology and neuroscience, of the 'hypnagogic' or 'mild trance' state which story-listeners may enter.

The idea of a shared hypnagogic state has been harnessed in therapeutic practice. Alida Gersie claims with regard to her own therapeutic story-making groups: 
Such story-work can be used to create access to communicative practices that demonstrate commitment to the community's well-being. It also fosters ways of being together that provide everyone with some joy. (Gersie, 1997, p. 24)

The idea that listening to stories together may heal rifts, reconnect the isolated or divided, allow for moments of connection which bypass conventional social defences, or even bring about shared epiphanies, is a powerful one. Thus, during my residency at Maple House, I aspired to offer workshops which would provide, metaphorically, 'another room' within which those present could safely meet. While each individual was mired in their own issues, anxieties, fears, obsessions and depressions, I hoped they might fleetingly experience the possibility of real connection with others, within the safe fictional or even fantastical bounds of the stories I brought them. Indeed, I believe I did glimpse such moments.

Yet Maple House convenes a population which is usually too transient to be a real community - who often sense, indeed, that they are better off not forming one. I did observe friendships forming within the setting, usually cautiously; but friendship groups were rare. Every week young people left, new ones arrived, and states of mind varied so much that every day brought a new human constellation. Every crisis affecting one resident could sweep up others in its wake, and the contagion effect sometimes brought unpredictable threats to each young person's journey of recovery. At other times, an easier atmosphere of cheerfulness would reign, but it could never be taken for granted. I wrote at the time that each week when I arrived for my storytelling session, I did not know what I would find:

Like a sailor visiting a port, I walk into the saloon looking for old friends or new acquaintances, and see what's up. Like the children climbing the Faraway Tree, I do not know what land I will be entering when I clamber up the ladder each week, or how welcome I will be. (Heinemeyer, 2015)

It was accordingly rare to feel that everyone present was 'together in the story'. Even gathering the group of young people to make a start was a delicate process - deciding where to sit, who was in, who was definitely out; who was listening with one ear, but with her eyes downcast and her back half-turned. Some warm-up games would form a fragile ring, and at some point I would usually tell a story - usually something either from long ago, or from far away. As it unfolded I would see or sense reactions. There was usually someone who liked the cadence of a storytelling voice while she was 
plaiting her friend's hair, but was possibly less interested in the story itself; someone who was fired up by a certain image in it; someone who was aggravated by it; someone who wriggled uncomfortably, as if he wanted to get away. There were usually one or two who gave themselves over to the story or whatever other thoughts and memories it summoned up for them, gazing just past me as images formed in their minds.

A colleague attended my Maple House workshop one day, and observed that I seemed more hesitant telling to this group than in other contexts: rather than giving a confident performance, holding their attention and meeting their gaze, I would often look down at my hands, as each of them was doing. I could not at the time explain why, but I think I felt driven to mirror the tentative mood in the room, so as to allow them to be alone, and to leave the story at any time.

The images that frequently came to my mind were that, rather than a circle around a campfire, my story was providing something more similar to a rock surface, with ledges and handholds for those who wished to hook onto it for a little while; or a wide open, windblown shore, sparse and exposed, with all of us aware of each other's presence but wandering separately.

\section{Listening alone (OR, Handwork)}

\section{The Stolen Child (2)}

When she awoke she was aware of a cold draught at her chest, and realized her baby was gone. She jumped to her feet and searched wildly all around the boulder, but all the way up and down the beach there was no-one to be seen. The waves were high and powerful, but still far off, and her clothes were dry. And so she had no choice but to make her way along the coast. Everyone she met, she asked if they had seen a baby, but there was never any news. By nightfall her feet were criss-crossed with cuts and she could not walk any further. She collapsed under a grassy outcrop, just in sight of a small fishing village.

Early the next morning she felt firm, strong hands lifting her to her feet, half-lifting her into a house, tucking blankets all around her in a bed, bringing some hot liquid for her to drink. She had no strength to do anything but comply. Kind women's faces clustered around her, voices asking her questions that she could barely understand. All she could do was repeat her question, 'Have you seen my baby? Where is my baby?' The kind faces now creased with discomfort and murmured a name, the name of someone who might know, or 
rather who might be able to deliver a difficult message they did not want to utter themselves.

They brought her to a camp outside their village and to a tiny caravan where a very elderly woman was drinking tea. The old woman clasped the young one's hands and told her, 'You were perhaps not wise to give in to your exhaustion on that particular shore. There is the hill just along from there, where the Old Ones live, the ones you call fairies. They are beautiful but they are not kind and they cannot make anything for themselves, not even children. And so they take them from us. I can tell you how to find the mound, but you will not get your child back from them without giving them something of equal value in return.'

The young woman was distraught - 'I haven't got anything of value, not even shoes for my feet.' 'I am afraid that is how it is, 'said the old woman, and repeated: 'The only thing you can do is bring them gifts of equal value.'

The young woman stumbled out of the caravan and back down to the shore. It was still windy, bleak, rocky, with nothing between the sea and the sky that could help her. Nothing but the bones of dead seabirds, feathers blown off their breasts, sticks of driftwood thrown up by the waves. Picking up the bones and sticks she started to play with them, forming them into the curved triangle of a harp. She grasped at the straw of an idea. She pulled down her hood and plucked out some strands of her hair - she had thick, long, red-brown hair and started to tie the shape together into a firmer framework. She plucked more strands of hair and strung the framework like a real harp, pulling each one to the right tension.

She looked around her again and started to gather the soft downy feathers. Again with strands of hair she bound them into a kind of cloth, soft and warm and light. More and more of it she made until it was big enough to form a sort of shawl.

It was on those occasions when we had crafts in front of us while exchanging stories at Maple House that a cosy household atmosphere would develop, resembling the Hindu-Buddhist idea of 'enstasy', defined by Julian Stern (2015, p. 111) as 'describing the virtue of comfort in solitude'. Rather than the intense interpersonal mood in which a story is often created between storyteller and participants, I would sense that we were holding a space for each person to be alone. Sometimes the young people would bring in their own knitting projects, doodling, colouring or friendship bracelets; other times I would bring beans to shell or yarn to braid. The sensory engagement and sense of usefulness this engendered seemed to enhance the experience for 
all concerned; sharing tips on how to do a particular task also offered further moments of connection.

The day I told 'The Stolen Child', I brought willow frameworks on which I invited the young people to weave their own gifts for the fairies.

It was Walter Benjamin, in his famous essay 'The Storyteller' (originally published in 1936) who pointed out the integral link between story-listening and handwork of various kinds. One reason for this was the 'orientation towards practical interests' (Benjamin, 1973, p. 86) of many storytellers, and the tendency to include practical instruction in stories; but he feels it to be primarily because

This process of assimilation, which takes place in depth, requires a state of relaxation which is becoming rarer and rarer ... Boredom is the dream bird that hatches the egg of experience ... [The gift of listening to stories] is lost because there is no more weaving and spinning to go on while they are being listened to. (ibidem, p. 91)

There is, of course, no simple opposition between aloneness and communitas, as is embodied in the name of this conference, 'Alone Together'. In another detailed study, Patrick Ryan and Donna Schatt (2014) interviewed adults aged 19 to 45 who had been part of the same long-running education programme at the Chicago Laboratory School, in which children were told stories for half an hour a week, every week, for many years. The interviewees, 10 or 20 or 35 years later, recalled that were never asked by their teachers to discuss or write about these stories. Nor did they recall acting them out in their playground games; indeed, most of them could hardly remember the details of any of the stories they had been told. Yet universally, they had intense memories of the physical experience of these numerous storytelling sessions - the smell of the library, the feel of the mat on which they sat crosslegged to listen, the sensation of sitting there with others, being alone in their own heads. They were also unanimous in declaring that this experience had impacted on them as people as well as on the culture of the school, influencing their interests and values, relationships and future careers in ways too unfathomable to track. Yet this experience was arguably a solitary one as much as it was a communal one; not 'another room' in which they met, but a territory each listener mapped individually. 


\section{Leaning together}

Petra Kuppers, describing a storytelling project she ran with a group of women experiencing mental illness, draws on Jean-Luc Nancy's (1991, p. 35) observation that 'singular beings lean together' - each participant was an 'I' in a kind of isolation, not sharing a story, or even an interpretation of a story, but leaning in towards it. Storytelling (indeed all communicative interaction) requires that we accept this impossibility of real meeting. Geoff Mead (2011, p. 40) cautions that while storyteller, story and listener are in a triangular relationship with each other, 'the crucial relationship between the audience and the story is beyond the storyteller's grasp'.

Emmanuel Levinas underscores this acceptance that we can never know another person, that we are in a sense trapped within our own selves. It is only in accepting this that we can sometimes transcend our own boundaries and thus grow and change, reaching towards other people to help us to do so:

We do not need to know the other person (or thing) as he is in himself, and we shall never know him apart from acting with him. But unless we desire this, and go on trying, we shall never escape from the subjectivism of our systems and the objects that they bring before us to categorise and manipulate. We do not get rid of our thoughts and feelings by ignoring them or by any other means. But we may seek to transcend them, first as individuals and only later, perhaps, as a group. (Levinas, 1969, p. 18)

Moreover, it is a surprising paradox that in storytelling - the very image of human community and communion - we often tell stories of lone or lonely characters. In this respect it is important to remember Lev Vygotsky's (1967) simple but vital observation, that creative acts depend on our combining images already existing in our memories. Therefore, in summoning up the heroine of 'The Stolen Child' I am in fact sharing my own experience of aloneness with my listeners, because when we tell stories, even ones of long ago and far away, we invariably draw on our own experiential repertoire to form the images in our own minds.

To underline this point I will refer to another project, and another story. I began a mental-health-focused project called The Tale Exchange, with four support groups for young people, by telling each group a story of the Siberian heroine Belye (based on a transcription by Van Deusen, 2001). I told how Belye isolated herself in a little house on a rock to see if a lover would come, 
how she was tormented by a family of brothers, how she rescued a little boy from their bullying, and then how she brought down the power of the waves to toss the brothers' canoe and punish them. The purity of this tale, the utter self-reliance of the heroine, brought me back to certain moments when I realised that ultimately, I am alone in the world. Despite the love of family and friends, no-one could endure the pains of giving birth with me; no-one's companionship is enough to give my life meaning at points when it seems to have none. I could not tell the story of Belye without letting such personal experiences shine through it, like light through a mesh.

The Tale Exchange project acknowledged this essential aloneness, both in its subject matter and in its structure. It resisted, or at least postponed, the usual remedy of participatory arts projects: the invitation to come together and collaborate. Rather than bringing all the young people together, I visited each group separately and told them this story. They then worked - in their own separate ways, collectively or individually as appropriate - with different artists, in different artforms, to make creative responses to it. Groups then posted their responses to each other, and if they wished, made a second creative response through visual art or creative writing. In so doing we were effectively doing what I have described, in relation to other projects, as 'communicating around corners' (Heinemeyer, 2018). It was only later that everyone involved met in one room to share what they had made. We deliberately made no attempt to coordinate their perspectives on this strange story, to summarise or crystallise them, but only to exchange them. Young people stayed in their groups but sometimes crossed the room to each other's tables, visited each other, showed what they had made, and acknowledged each other's experiences, expressed through their words or images. The story had thus created a shared space of expertise between the groups of young people before they ever met each other.

One young woman received a drawing, sent by another group, of Belye calling out to sea, calling up the waves to save her and to punish the brothers. She chose to write a poem in response to this, and both this poem and its creation process seem to encapsulate the interplay of aloneness and togetherness:

\section{BELYE CALLING OUT TO SEA}

If I call out to you, can you hear me?

Would you listen?

Options are few and you don't know how much I need you right now.

I am lost, scared but my fear is subdued because I trust you.

Not just because I have to, but I want to. 
It's roaring now so please offer me your protection

Lead me in the right direction.

I am screaming with you to fight this

Together we cannot be dismissed

I believe in this

I believe in us

I believe in you

I believe this is something I can get through

Even though it seems that there is no way out

As the sky and the sea merge together to become one shade of blue

I know I have you

I am filled with so many hopes and aspirations

I will not let this be my demise

This water will not produce unrelenting waves of devastation

They are mine

They are with me

They are on my side

So please don't expect me to fall and crack

As I can withstand any attack

I am strong as I ask the winds to blow

To finish the event, the poet we had brought in to bear witness to the whole exchange gathered up all the threads that participants had brought into the room, and wove them into one poem; this made explicit the fact that each person was going away with their own version of the story, but that all had leaned in towards each other in the space.

\section{Weaving together}

\section{The Stolen Child (3)}

The young woman made her way along the shore to the fairies' hill. She hid herself away to observe until she saw two figures enter, showing her where the door was. There she presented herself and found her entrance barred by an elegant young man. Nothing she could say would persuade him to let her in, until she held up the shawl she had made. His eyes glittered and he reached out to grab it, but she whisked it away until he understood he would need to bargain. He stepped to the side to let her pass, and she handed over the shawl. 
She made her way down passageways that grew darker and cooler, before growing lighter and warmer again. Ahead of her was a warm glow and eventually she found herself emerging into a high-ceilinged chamber, full of people staring at her, the Old Ones, the fairies, beautiful but too wide-eyed, too beautiful in fact. In the midst of them all, on two thrones, the King and Queen, and on the King's lap, a bundle - a baby - her baby. She caught her breath that was trapped in her throat, and pushed through the throng all the way to them. She lifted up her harp and began to play. A golden music filled the chamber and echoed from the walls. The King and Queen were entranced.

'Give me my baby,'she said.

'Give me the harp, 'said the Queen.

'You will give me my baby first.'

And in the end her hand was on her child before she gave them the harp. She did not say another word but took her baby in her arms and walked out through the tunnels, back out into the daylight and straight down to the beach. There she lit a fire, sat down on a stone, and fed her child for the first time around their own hearth.

There is almost always a moment of tension after a story, as everyone present knows the transition must be made back into normal time and - I suppose - out of being alone together. There's a feeling that anything you say might be the wrong thing, or at least irrelevant, and might undermine whatever the story had been for each one present. It is a necessary violence, but I cannot always face it. On the occasion on which I told 'The Stolen Child' in Maple House, the setting's teacher sensed this, and stepped in himself to help me with the right words. I can no longer remember what they were.

It was one young woman's last day at Maple House. Luna had been there for many months and, as a keen creative writer and artist, had been one of the most faithful participants in all of my storytelling workshops. She had finished weaving her dreamcatcher, and brought it across the room as a gift for me.

\section{References}

Benjamin, W. (1973 [1936]). The Storyteller: Reflections on the Works of Nikolai Leskov. In H. Arendt (ed.), Illuminations (pp. 83-109). London: Fontana.

Gaylord, K. (1983). Theatrical performances: Structure and process, tradition and revolt. In J. B. Kamerman \& R. Martorella (eds.), Performers \& Performances: The social organization of work (pp. 13-49). New York: Praeger Publishers. 
Gersie, A. (1997). Reflections on Therapeutic Storymaking: the use of stories in groups. London and Bristol, Pennsylvania: Jessica Kingsley Publishers.

Heinemeyer, C. (2015). Storytelling at an adolescent mental health unit. Storytelling with Adolescents - research through practice. http://storytellingwithadolescents.blogspot.com/2015/03/storytelling-at-adolescent-mental.html [accessed: 10.02.2020].

Heinemeyer, C. (2018). Adventures in storyhacking: facilitating indirect inter-community dialogue through storytelling. Teaching Artist Journal, 16, 3-4. DOI: 10.13140/RG.2.2.11861.27361.

Kuppers, P. (2007). Community Arts Practices: Improvising being-together. In P. Kuppers \& G. Robinson, G. (eds.), The Community Performance Reader (pp. 34-47). Abingdon: Routledge.

Levinas, E. (1969). Totality and Infinity: an essay on exteriority. Tr. A. Lingis. Pittsburgh: Duquesne University Press.

Mead, G. (2011) Coming Home To Story: Storytelling beyond happily ever after. Bristol: Vala Publishing.

Nancy, J.-L. (1991). Inoperative Community. Trans. P. Connor, L. Garbus, M. Holland, \& S. Sawhney. Minneapolis, MI: University of Minnesota Press.

Ryan, P. \& Schatt, D. (2014). Can You Describe the Experience? Storytelling, Self, Society, 10(2), 131-155.

Stallings, F. (1988). The web of silence: The storyteller's power to hypnotize. $\mathrm{Na}$ tional Storytelling Journal, 5(2), 4-13.

Stern, J. (2015). Soul-searching and re-searching: action philosophy alone. Educational Action Research, 23(1), 104-115. DOI: 10.1080/09650792.2014.994015.

Turner, V. (1969). Liminality and Communitas. In V. Turner (ed.), The Ritual Process: Structure and Anti-Structure (pp. 94-130). Chicago: Aldine Publishing.

Van Deusen, K. (2001). The Flying Tiger: Women Shamans and Storytellers of the Amur. McGill-Queen's University Press.

Vygotsky, L. S. (1967). Imagination and Creativity in Childhood. Journal of Russian and East European Psychology, 42(1), 7-97. 
